\title{
THE CHANGE OR STABILITY IN THE PERCEPTIONS: A READING ATTEMPT WITH GRACE ELLISON AND MARTHA NICOL
}

\author{
Orkun KOCABIYIK ${ }^{1}$
}

\begin{abstract}
Travel literature and self-narratives are the most inclusive sources in which the perceptions of travellers and their subjective accounts can be analyzed and followed. They have been major genres in British literature for a long time in the forms of letters, narratives, and diaries in the sense that they offer "factual" information pertinent to historical scholarship, as well as fictional elements otherwise found in novels. In this respect, this study covers two female travellers and their accounts in terms of comparative basis. In her account titled An English Woman in Angora, Grace Ellison writes about her adventures and observations in Turkey right after Turkey's War of Independence in 1922 when the new Republic of Turkey was established. On the other hand, Martha Nicol stays in Izmir as a nurse and gives service in British Army Hospital in Izmir during the time of Crimean War (1853-1856). Apart from their male counterparts, one might consider the inveterate Turkophilia of both female travellers in their accounts through their discourses. In this regard, with a textual comparison of the above-mentioned accounts, the purpose of this paper is to reveal the change or stability by exploring the discursive strategies deployed by Ellison and Nicol towards and after the establishment of Republic in Turkey.
\end{abstract} Republic

Keywords: Travel Writing, Turkophilia, Women travellers, Discourse,

${ }^{1}$ Yardımcı Doçent Doktor, Akdeniz Üniversitesi, Edebiyat Fakültesi, İngiliz Dili ve Edebiyatı, okocabiyik(at)akdeniz.edu.tr 


\title{
ALGILAMADA DEĞişiM YA DA SÜREKLiLIK: GRACE ELLISON VE MARTHA NICOL ÜZERINDEN BIR OKUMA DENEMESI
}

\begin{abstract}
ÖZ
Seyahat edebiyatı şüphesiz ki, yazarının veya seyahati gerçekleştirenin taraflı/tarafsız düşünce ve gözlemlerini analiz edebildiğimiz yegâne yazıll eserlerdendir. İngiliz yazınında ise çok eskiden beri günlük veya anı gibi formlar içinde gerçekliğin yanı sıra abartı ve kurmacayı da takip edebildiğimiz edebiyatın bir türüdür. Kadın gezginlerin ise bu tür var olduğundan itibaren kendi anlatı yöntemleri mevcuttur. İşte bu çalışmamızda İngiliz gezi edebiyatının, özellikle on dokuz ve yirminci yüzyıllardaki örnekleri ele alınacaktır.Martha Nicol'ün İsmir ya da Smyrna: 1855'de İzmir'deki İngiliz Hastanesi başlıklı gezi yazılarıyla, 1923'de Türkiye'yi ziyaret etmiş olan başka bir kadın gezgin olan Grace Ellison'nun Ankara'da Bir İngiliz Kadın adlı eseri söylem açısından karşılaştırılacaktır. Bu bağlamda bizim için sorulması gereken soru şu olmuştur: Osmanlı İmparatorluğu dönemindeki Türkiye gözlemleri, Cumhuriyetin kurulmasıyla, dolayısıyla rejim değişikliğiyle, ne şekilde bir değişime uğramıştır? Daha doğrusu, İngiliz kadın gezginlerin eserlerinde bu değişim kendini ne şekilde göstermektedir.
\end{abstract}

Anahtar Kelimeler: Gezi Edebiyat1, Türkofili, Kadın gezginler, Söylem, Cumhuriyet Dönemi

Kocabiyık, Orkun. "The Change Or Stability In The Perceptions:A Reading Attempt With Grace Ellison And Martha Nicol". idil 6.39 (2017): 3011-3020.

Kocabiyık, O. (2017). The Change Or Stability In The Perceptions:A Reading Attempt With Grace Ellison And Martha Nicol. idil, 6 (39), s.3011-3020. 
Travel literature and self-narratives are broad sources in which the perceptions of travellers and their subjective accounts can be analyzed and followed. They have been major genres in British literature for a long time in the forms of letters, narratives, and diaries in the sense that they offer "factual" information pertinent to historical scholarship, as well as fictional elements otherwise found in novels. In this respect, this study covers two female travellers and their accounts in terms of comparative basis.

In her account titled An English Woman in Angora, Grace Ellison writes about her adventures and observations in Turkey right after the Turkey's War of Independence in 1922 when the new Republic of Turkey was established. On the other hand, Martha Nicol stays in Izmir as a nurse and gives service in British Army Hospital in Izmir during the time of Crimean War (1853-1856). Apart from their male counterparts, one might consider the constant Turkophilia of both female travellers in their accounts through their discourses.

In this regard, with a textual comparison of the above-mentioned accounts, the purpose of this paper is to reveal the change or stability by exploring the discursive strategies deployed by Ellison and Nicol towards and after the establishment of Republic in Turkey. By this means, this paper elaborates discourse and characteristics of women travel writers. In the recent years, accounts by male travel writers have received much attention by the researchers. Yet accounts written by female travellers are still almost untouched by literary scholars. Here, it might be necessary to give brief background for both travelogues in order to see the motive behind their perception and development of a new discourse in their accounts.

Martha Nicol was one of the devoted nurses/travellers who served from March $28^{\text {th }}, 1855$ to December 1855 at Izmir British Army Hospital. As many contemporary travellers did, Nicol also compiled her anecdotes during her stay in Izmir once she returned to Britain. She published her memoirs as Ismeer, or Smyrna and Its British Hospital in 1855 by a Lady. On the other hand, Ellison as a journalist and a traveler, had the chance to receive part of her education in France at the "Convent des Annonciades," "Boulogne sur-Mer, Ecole Normale Superieure," and University of Halle. Like her former sister Martha Nicol, she also worked as a nurse in World War I. "It was she who would go to the USA in 1919 to solicit help from young American women to fill the gap left in French hospitals by the nuns who left their country to go to places like Turkey" (Ternar, 1994: 98). Her second visit to Turkey gave an opportunity to write An English Woman in Angora as a second account on Turkey. Ellison might be considered to have followed Virginia Woolf's steps in terms of women's solidarity in a way of "a room of one's own." 


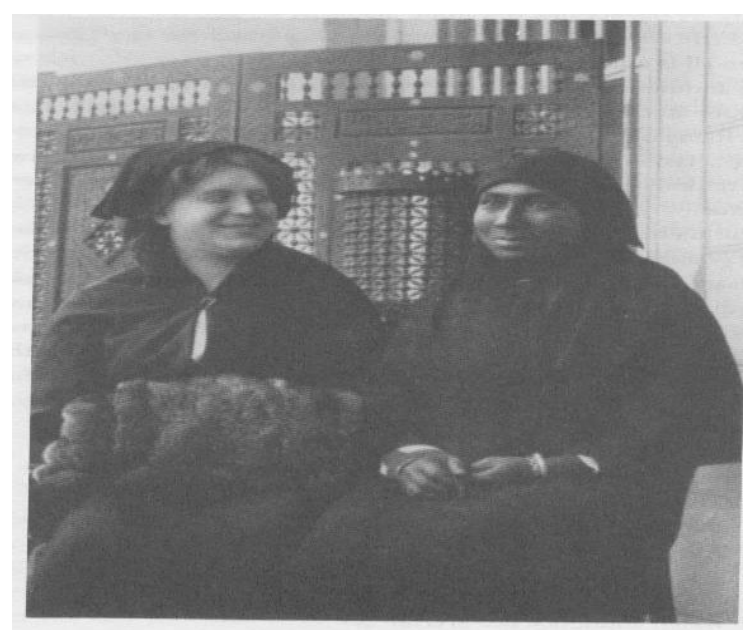

Photograph of Grace Ellison and her Turkish servant, Miss Chocolate 1915. in Yeshim Ternar, The Book and the Veil: Escape From an Istanbul Harem. Montreal: Vehicule Press, 1994. 60.

As one might understand form the text that Nicol's personality is rather a patriotic British nurse revealing with her Presbyterian background. Through the first chapters of her account, she gives descriptive information about the topography and some other personal anecdotes on the way to Izmir as they are generally connected with either British patriotism or men treating the ladies in various manners. Later chapters cover her time in Izmir and hospital concerning the sanitary circumstances of their working area and environment of Izmir. Many details on Izmir, especially on daily life, are evaluated and observed by Nicol in her own discursive style. This kind of description might be considered exceptional in terms of the narrative observations when her text is compared to those of male counterparts. To be more precise, as an English woman in the East, she caught the opportunity to see the inner structure of the family life of both Muslims and non-Muslims. Different from most of the former male-oriented travellers, Nicol, just because of her gender and duty, not only had many opportunities to observe family life but also met with various local administrative bodies of Ottoman Empire. Her observations came out during the period of Tanzimat reforms representing a key milestone in the westernization attempts of the Ottoman Empire. Ottoman historian Philip Mansel also mentions the privileged nature of the female travels by quoting from Niocls's own account that "the Muslim women of Smyrna...covered from head to toe in white veils...Behind their veils, they appeared 'inelegantly protuberant to the English eye"' (Mansel, 2010: 31). Different from Ellison's first encounter with Izmir, in her first embarkation to the town, Nicol still carries her own nineteenth century cultural baggage in the following lines: 


\begin{abstract}
I came on deck, to take my first view of "the Queen City of the Levant"-Ismeer, "the Beautiful"! If it were possible for Smyrna to have looked ugly, it must have done so then. But no; the bay, with its splendid setting of hills and mountains of every from and hue; the town, commencing literally in the sea, and reaching, with its picturesque houses, mosques, minarets, and groves of cypress, nearly to the top of the hill on which it is built, and which is crowned by a ruined castle, while a little further down, conspicuous from all quarters, with its single cypress, stands, isolated and alone, the grave of Polycarp; all formed a picture which even then convinced one it had not been misnamedIsmeer, "the Beautiful.” (Nicol, 1856: 199-200)
\end{abstract}

Even these kinds of narrative strategies were common in travel accounts; Nicol in her discourse is different from the many other British travellers who were more inclined to imitate one another's discursive method, even on the syntactical level. In the above-mentioned first encounter scene, Nicol seems to echo the previous travellers' common narrative strategy praising the panoramic outlook of the topography as one might also see common words such as "the Beautiful," "the Queen City," "picturesque houses," etc.

On the other hand, Ellison's first panoramic impression on the board about the same town in a different time seems to be influenced by her own cultural baggage along with the political climate that is recognizable at first sight when the below quotation is compared to Nicol:

For Orientals, the sky is no less variable and uncertain than the political horizon. In the space of an hour the sea, calm as a lake, has been transformed to a roaring torrent. Smyrna in the distance, and we are battling forward through one of the worst storms of the season...huge waves washing into staterooms soak the carpet, thunder and lightning rage overhead; as in the grim battle of life, we can but hold on till the clouds pass...As we draw nearer it is no longer necessary for us to gaze upon the devastation; the blind cloud catch a strong smell of burning and in a few moments, we see that even the rains have not entirely quenched the clouds of smoke still rising from the tobacco factories. (Ellison, 2014: 43)

Ellison's account of journey takes place in the aftermath of Turkey's War of Independence when Ottoman Turkey was collapsed and new Republican Turkey established. Even this journey was the second visit to Turkey, this time, she clearly was witnessing one of the most crucial regime changes in history. The nationalistic attitudes concerning her own country (Britain) also affect her exuberant Turkophilia in her word choices such as "political horizon," "battle of life". On the other hand, these 
kinds of discursive choices are not present in Nicol's account as she was in Izmir while there was no grand political change.

Instead, interestingly enough, Nicol notes some other detailed features of the Turkish community. Travellers' first encounters in the East after first setting foot on soil were usually with Christian minority communities such as Levantines. From the beginnings of her account, Nicol chooses a more Turkophile tone in her descriptions and contrary to the common travellers, she meets with the local administrative Turkish elites, like her prospective sister Ellison: "These poor Turks were always so kind and polite to us. Never-although proceeding against all their ideas of propriety, by taking hold of a gentleman's arm - have they shown anything but courtesy and civility...I always felt perfectly safe with the Turks" (Nicol, 1856: 185-187). As one need to think on the common ground for the lady travellers' Turkophile style in their accounts, it is also probable to see the same resemblances in other former lady observers to the destination such as Lady Mary W. Montagu, and Julia Pardoe. Even from the different periods, this common ground in their narrative style might come not because of their gender but how they were influenced by their former models.

As is commonly known, by the nineteenth century, people were traveling more for various reasons such as mere adventure, missionary intent, classical and religious reasons. In addition to those, traveling for nurses was unique in terms of its aim and specific gender-based dependencies founded first by Florence Nightingale. One of the most primary differences of Nicol's account from the other travellers of the time is her way of handling the daily life, the detailed descriptions of the Turkish households, and the manners of the women in Izmir during the nineteenth century. Nicol benefitted from the experience of attending many wedding ceremonies, household rituals, religious days, and womanly gatherings in Izmir, thereby observing the small details along her eight-month stay in the city. While doing this, it is noteworthy to see her stylistic choices. In first place, different from Ellison, she chooses to use English words which generally evokes either the symbols of the empire or patriotic feelings about her own homeland such as, "The Pasha," "Albanian-Ottomans," "mollah," or "William Wallace." On the other hand, Miss Ellison is different in choosing English words such as, "Capitalists," "Nationalism," "Independence War," "democracy" which refers to the new born republic.

During and after her fourth trip to Turkey, Grace Ellison was considered as courageous to proceed into inner Anatolia heading from Izmir to Ankara, the new capital. She also mentions in her account the general opinion that it was more than dangerous to be an Englishwoman in Anatolia immediately after the war. After defeating the Ottoman Empire in the war, occupying Istanbul, and supporting the Greek invasion of Anatolia, the British were not welcomed in Turkey. As one can also 
notice during the first chapters of her account, hardly anyone Ellison meets can believe that she is making the journey alone, and many men advise her to pretend she is American for her own safety. But instead of accepting this idea she responds as "God forbid," she insists on carrying a Union Flag around with her out of loyalty to British Empire as her former colleague Nicol reveals her homesickness with more historical allusions. The obvious contradiction between the patriot voice and the passionate Turkophile continues throughout her account and Ellison spends pages. Below quotation reveals her passion when she reaches from Izmir to new Republican capital Ankara:

The main road passes the Grand National Assembly on the way to the few shops. The restaurants make a fair show of Turkish delicacies, like your ekmek kadaif and kebab. We pass two hans (i.e., inns) as primitive in comfort as appearance, built of mud in which large holes can be seen, and full of danger to the unwary on their rickety staircases. The "commercials" in their yailis, on camels or donkeys, however, can find no other or better accommodation. There are pictures of Ghazi Pasha all over the town, and in one or two bookshops you can also buy his principal colleagues, patriotic postcards, and other "Nationalist" pictures in gaudy colors. (Ellison, 2014: 136)

Such choice of words clearly brings out her attitude about recently established system in these lands after five hundred years of the dynasty of the Empire. On one hand, it seems a stunning experience for Ellison to witness these changes in Turkey, on the other, she seems also nationalistic in terms of her own homeland, British Empire. In fact, Ellison writes pages on Britain's "terrible and tragic bungling," complaining about British policy toward Turkey has gone "woefully and willfully astray" (Ellison, 2014:45-46). While she was talking with the governor of Izmir at one point, it was recognized by the careful reader that apologizing for British misdeeds is part of the motivation behind her fourth trip: "the Turks shall see that one Englishwoman can stand out against injustice... God willing, may I, as one Englishwoman and a friend, preserve for my country some last shred of respect and faith in our honor among the Moslems of Turkey and India, Egypt, Persia, and Palestine" (Ellison, 2014: 59-60).

After punishing herself with her own words, comes the praise for the resistance forces in Anatolia and thus, despite the total desolation of post-war Anatolia, according to her observation, everywhere "the marvelous atmosphere of a Great Birth" (Ellison, 2014: 63) of the republic could be felt. In the middle through her journey, in a humorously baroque language of the time, Ellison points the "voice that 
seems to cut through the chill air": "Here, where the civilisations of the world's childhood have flourished; here, on the ruins of the great Empire of the Ancients; here beginneth a new Turkey, the democrat of democracies" (Ellison, 2014: 129). Her antiHellenic attitude naturally accompanies Ellison's Turkish sympathies, and traveling through Anatolia gives her chance to observe the results concerning the destruction of every corner of the country in the aftermath of Greek retreat. "Greek atrocities," she writes, have left the land in a pitiful state, "bled white through twelve years of war... On every side lie smashed engines, burn railway carriages, and villages in ciders...The corn, so carefully hidden in pits, has been burned; the water, on which life itself depends, has been polluted" (Ellison, 2014: 101). In the midst of the "oppression of desolation," Ellison's admiration can only increase for the "resolute Turk" (Ellison, 2014: 103).

On arrival in the "bare and rough Asiatic fortress" (Ellison, 2014: 142) of Ankara, capital of the new republic, Ellison is hypnotized even more passionately by Turkish nationalist enthusiasm and the atmosphere. She arrives there while the preparations are being made for the Lausanne peace conference, but the danger of war breaking out again still waits at the horizon. She meets many of the independence war resistance pioneers, including Mustafa Kemal himself, and has not a negative impression about any of them. The future Ataturk is "the greatest man in Turkey today" who has "accomplished miracles"; Halide Edib Hanim is said to be revered by the Turks "as their Joan of Arc" (Ellison, 2014: 155-157). Throughout her account, Ellison's tone is appreciative:

Here in Angora, I see them coming along their one wide road. All mingled without a thought of social distinctions; all intent upon the same goal - their country's freedom; all like proud of the price they have paid - officers and deputies, ministers and civil servants, soldiers, peasants, and caravan drivers. Are not these, then, the one true democracy of the world? (Ellison, 2014: 162)

Likewise, the reader also witnesses her implementing much of the puritanical "nativism" of the nationalists in Ankara (Asako, 2015: 6). After her stay in Ankara, back to Istanbul through the end of her travelogue, she seems shocked by the cosmopolitanism of the Pera (Beyoglu) district:

...what a terrible warning one can take from Pera! I had not realized the danger of losing oneself in the ambition to be truly cosmopolitan. These people belong to all nations and have the souls of none...In Anatolia, I found two forms of inborn honour: 
the 'nationalists' and the 'primitive peasant.' In Pera I stepped from Tokatlian's Hotel to the Embassy with the feeling that someone is going to stab me in the back. (Ellison, 2014: 288)

Ellison ends her travelogue with some observations from the Lausanne Conference in 1922-23, where a "final agreement was struck between the Turkish side and the allied powers" (Precious, 2003: 43). The "Great Birth" of a new republic that Ellison mentions in Anatolia reached its ends. Perhaps, her deep Turkophilia, resists against the wave of common international opinion for the Turks at the time, had played small part in helping the new Republic secure a peace.

In conclusion, the change in political relations between Turkey and the UK after Ataturk's revolutions and their reflections in travel writing is crucial to understand the change of the discourse. Therefore, the main focus of this paper is the differences in the female accounts of travel to Turkey before and after Ataturk and the revolution. The crucial question might be: Do travellers focus on political relations between the UK and the Ottoman Empire or does the recently established republic affect the travel accounts that they write? In this regard, few particular narrative shifts can be observed in Ellison's travelogue when it is compared with Nicol's account. Firstly, Nicol seems to be interested in more sanitary and social circumstances than the political milieu or the inner structure of the Ottoman Empire that shapes her overall discourse throughout her account. Ellison on the other hand, also because of her occupation, deals more with the political milieu of the newly established republic and for this reason, her choice of words particularly reveals her interest and tone of the account. Discourse-wise, their 'non-changing' or stable tone seems to be inveterate Turkophilia. For the female voices about Turkey, this kind of stylistic similarity is not only observable in Nicol and Ellison but also in some of their former sisters such as Lady Mary W. Montague, Julia Pardoe or Lady Elizabeth Craven. 


\section{Works Cited}

Ellison, Grace. An English Woman in Angora. Cambridge: Cambridge University Press, 2014.

Leidlaw, Christine. The British in the Levant, Trade and Perceptions of the Ottoman Empire in the Eighteenth Century. London: I.B. Tauris Publishers, 2010.

Lewis, Reina. Rethinking Orientalism: Women, Travel and the Ottoman Harem. Rutgers University Press, 2004.

Mansel, Philip. Levant: Splendour and Catastrophe on the Mediterranean. London: John Murray, 2010. Print.

McKenzie-Stearns, Precious. On a Mission: Grace Ellison's An Englishwoman in a Turkish Harem. Unpublished MA Dissertation, Wilmington: University of North Carolina, 2003.

Nakai, Asako. "Shakespeare's sisters in Istanbul: Grace Ellison and the politics of feminist friendship.” Journal of Postcolonial Writing, 51:1, 22-23, 2015.

https://doi.org/10.1080/17449855.2014.983698

Nicol, Martha, Ismeer or Smyrna and its British Hospital in 1855 By a Lady. London: 1856.

Ternar, Yeshim. The Book and the Veil: Escape From an Istanbul Harem. Montreal: Vehicule Press, 1994. 